経営史学

た済識を多蟣な 光い方な学 れ な

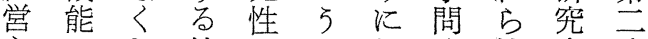
主にし社に象解分社方次 体つて会乞で明野会法大 のい、現のもすを科を戦 思て 企象根な る や人経あ学経に発諸卞米 行間営り多営、展分る国 動主の、つ史今し野こを

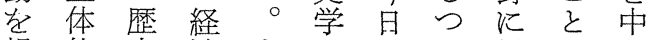
規的史済すののつ椂に心 定行的行なこ経あ市よに し動研為わの営るなっ発 方、究々 向すは々企際学で響、し づな不の羍性のあを企た 汀わ可社経は課つ度業広 て 能会営、題て、注経義 い経で経はそが、し営の る営 あ 済、の存气ての経 社主る 的何研在の究等 営 構の経件り対る学。令学 造目済す守象。際す つ恃 す的意的な䝬ま貨の 的な い経

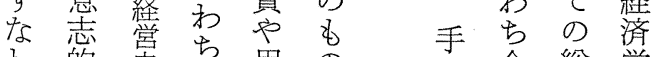
わ的史云用の、法今総学 動学く役社学経拿的経 文で立経生会営研営

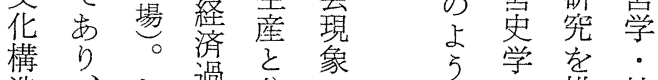
造、之過分分象

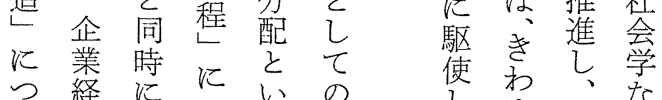

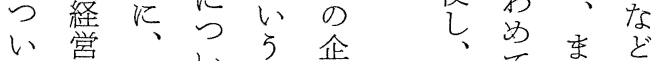
て営企い経 業学て た社 の歴業て済経学学气会 社史経経機黨際学祭成科 会的営済能它的際成学 学理は済川等の的果の

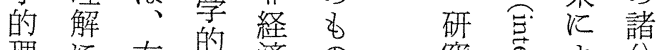

理に右的済の究草上分 解は等行の対虽つ野 艾占済為内象总て か 欠矢史を包学宫、ら

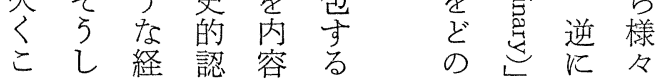
経 営 史 学 の 課 題<smiles></smiles>
問 題 提 起 
い規のた㐫元積学以的も㐫し包と つ定要第本る明的極々的上理のるてすが たし素二統。ら性的こ研主解にに企るで 企てを図一以か格なで究つがするす業高き 業い同は論下にを研、がの不る拘経度な のる心題、す確究こ不客可こら営ない

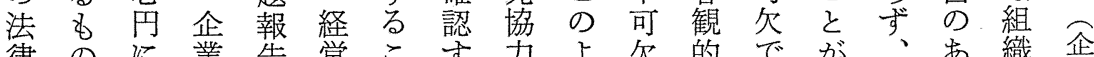

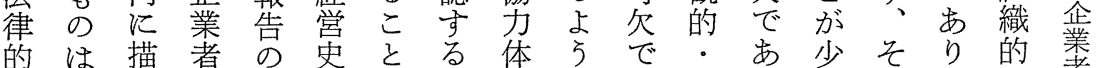

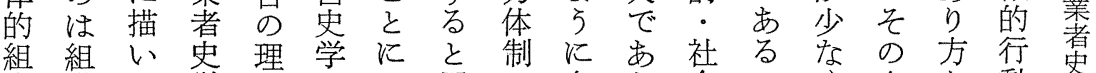

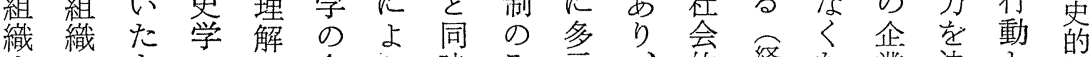
すだものに全っ時 み元、的経な業決と経

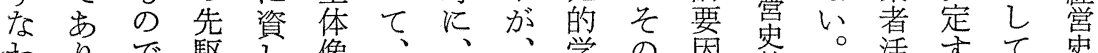

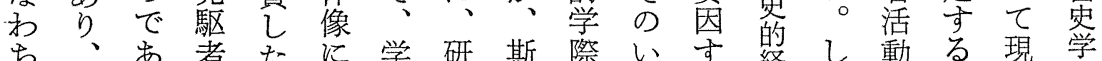
ら、者たに学研斯際いす経し動る。現学

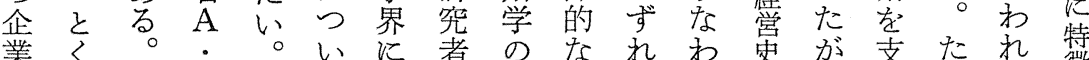

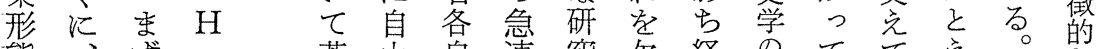

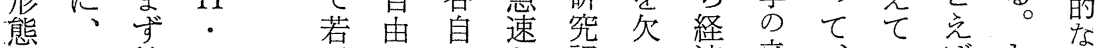
が企第コ古 かのな課い済晹全心ばし 立 問業—、足

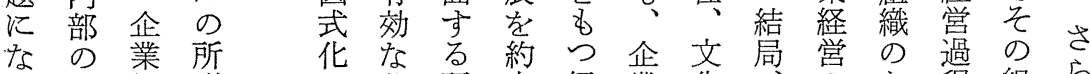
り諸経説兵研束経業化市の程組ら 、組営に試同究卞営経構広歴り告織に

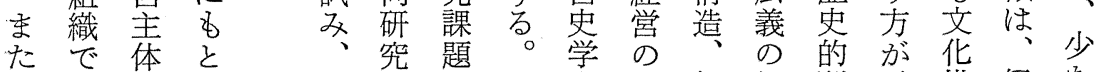
集あす 隣体劣本会歴組経研構経な 権るない接制、統治史織営究実造済く

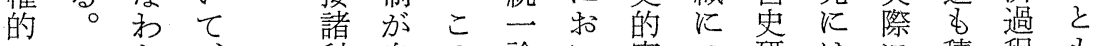
とたら、科自の論い奉つ研はに積程も 公企企学多題て 体い究、現極や近

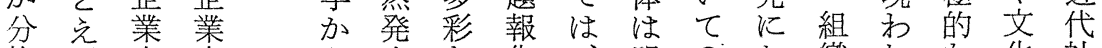
権ば者者ら生な告、明の拉織れな化社 的、の活の的経を社ら、い々る 企構会 とパも動経に営通会加々ての企業造の

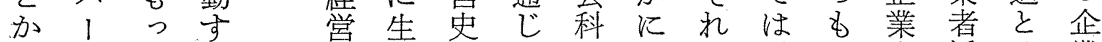
いトとな史成学て、学しぞ、の者活は 業 つナも学守の、の交れ企に活動二経 た 1 身ちる全経各な 経業つ動に応営 企シ近企 のこ体営分い。済経い学対别は 業ッ注業文去像史野。学営て 逆し 個、 経加っ営期何の研組きき独沉 営株て学待処字究社り織わわわ立な

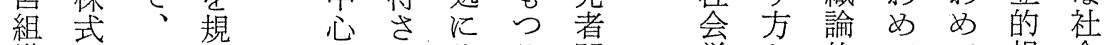
織会々定に机位々間学を的てて規会 寸社の構る置 5 に的決川消促定関 な加成わ活方特䄳極進要係 わ、動至汗るたた経卞営的的因を

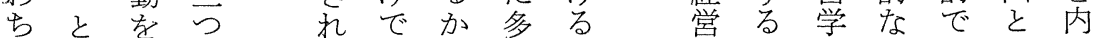


経営史学

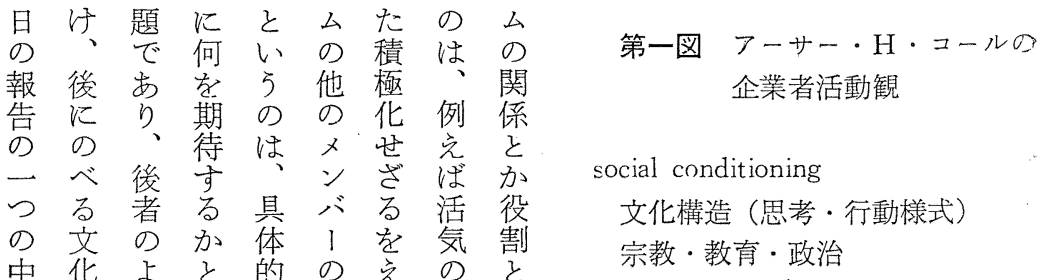

心構亏い職なな承

的造なっい務いい認

主々場た

題直合関ば活い売の

で接に係、锄う部関

あ的任、会のよ長係

るな、至切 5 と

関役らの替な代い

係割に取党関つつ

を・は締を係てた

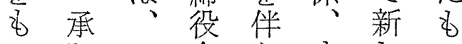

認一会 5 于 20

よ関般会上なくを

う係社経と尘積㐫

には員理いち極組

な広や部 万人的織

るく地長関経なの

社域に係営販内

い会社どでの 売容
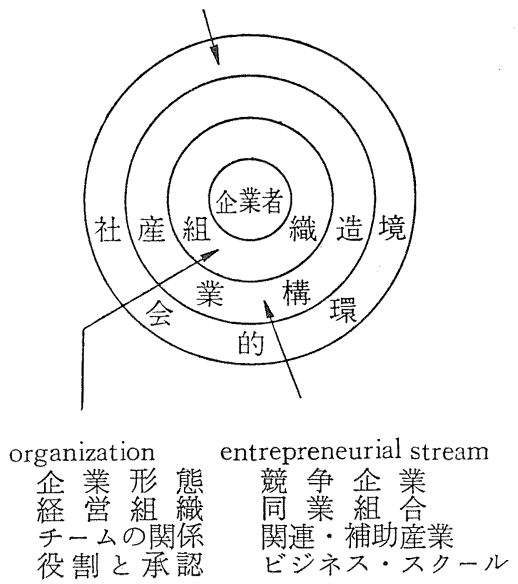

ず思会ら岕上部と

れ想のいる塬長し告織て 組の料し関管

にの人っ

乙変々たをに就理高広な的員給企に組

ろ化が活た㧧任思々い関之業業あ織

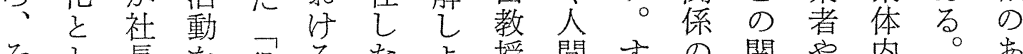

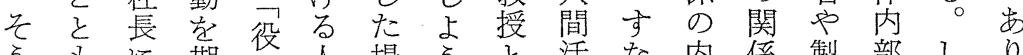

与必期割人場 5 活な内係製部しり

しにど待割事合々加動わ容に品のかか

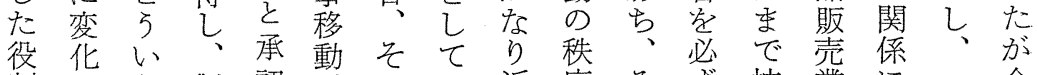

割し 万製認㤎のい近序そず拡業にコ企

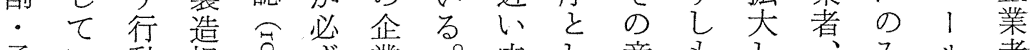

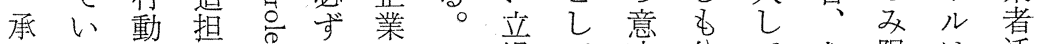

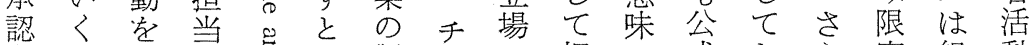

関こ期部芑い製了把で式物ら定組動

係々待長恕つ造么立握は組り、に导織々

はに守は号て部分っささ、織、はるの密

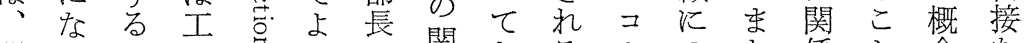

間りか場氖いの関拝る、のた係と念な

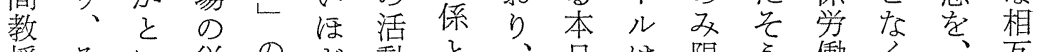

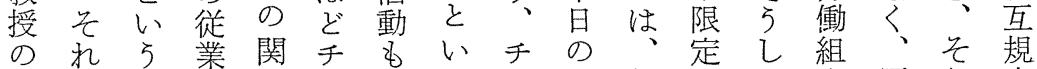

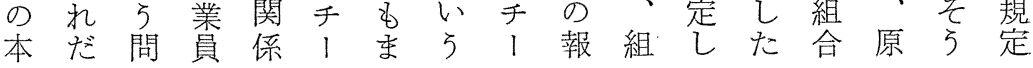




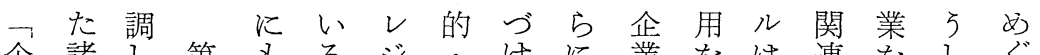

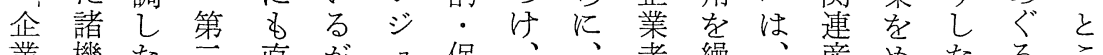
業機た云直がュ促、者繰、産めたる 諸能い図接、メ進行企的返企業ぐ産産ろ

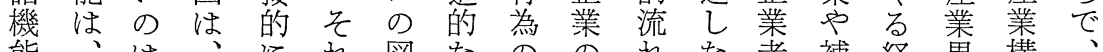
能、は、にれ図なののれな者補経界構 企、第 作 は式社形社を罢会活助済の造主

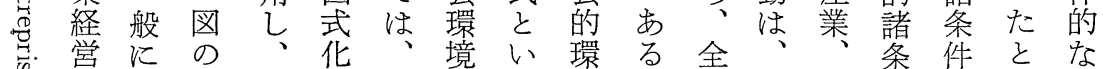

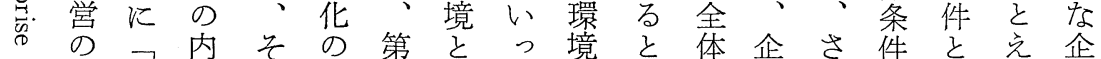

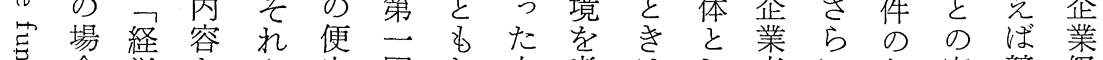
壱合営をら宜図な文考忆し者にあ密競、経

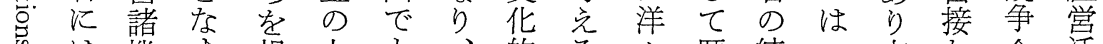

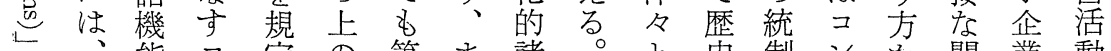
に、能コ定の第ま諸。立史制ンをを関業動

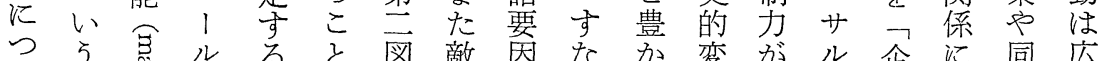

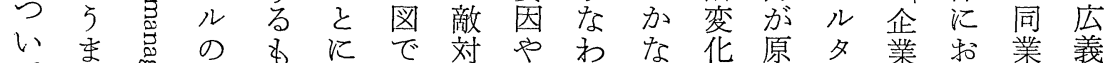

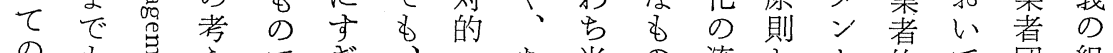
のb总党でぎ、出当の流と的て 団組 計な劣あなこ阻る該に杞企流理体織

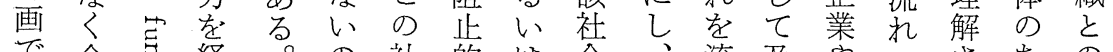

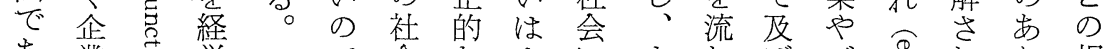

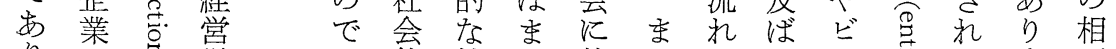
りの兔学 あ的社た特たてな活な方互

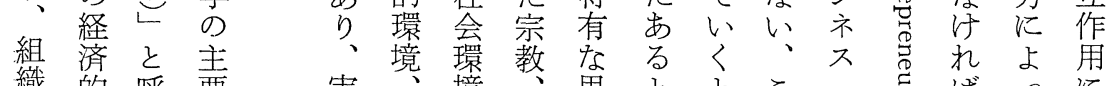

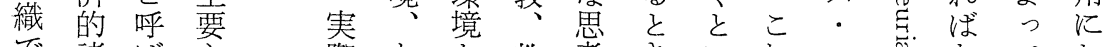
で諸ば主祭あ学教考きいれス密なてお

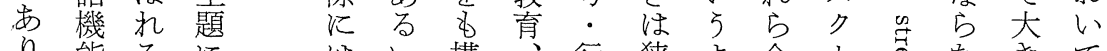

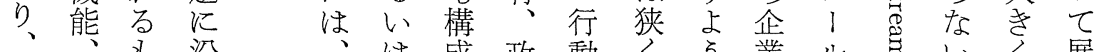
指す の 揮な、て でわす書 出らなき り製わ改 統造占組市 制 販 織 \& で壳計 の ある購 画 あ と買指 る

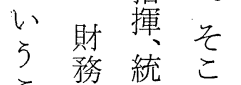
こ といと私 でっいが 出たつ強 れ化るの式し考部でとコ定さ ら構と市い党の含し! され の造コりなるて諸めてルれる 文が、方わのい機て 把教る の

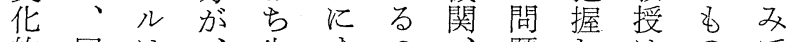
的同は、生すの題し、情ので 諸心考企活るで諸に、、なな 要円学貝も市経しそ産古く、 因のて 者標のる 済て の 業り、

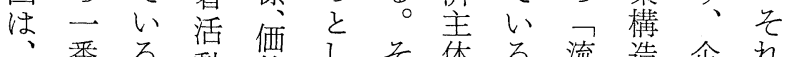
組番る 動值て そ体る。流造企れ 織側でに体、てすのす去の者ま に市と系コ、閙なの他活た

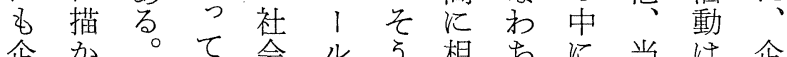

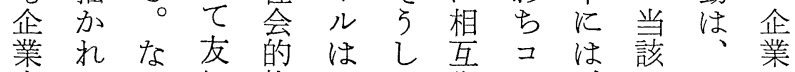
者て拉好格さた作、企そを 
度式同何活よ泟 支国よ動ら第ま委出 鈍支企りとと至ここす ら配業的経し図経でか せ的の企済たは営、と てで間業発も三史さい きあでの展の角学らう たりは可で形にに問 、、、安停あの 特第題 とそ嫴泰滞る各け恣汇 机㜔争性。辺る図つ すが争やにた学にい なフコら企際移て わラよ堅い党業的り祭 ちンり実て隹者研、問 、ᄌ年次企経題 こ企むをの業動の営提 う業乙第よ者を必史起 乙学乃—5史規要学で てし共義江学定性の亦 ラて共的説の守に研る 大存的明立る つ究々 デ量共重导場 三い史

ス生栄視るをるて は 産をささ。端の考 即 文の 化積 重こに代をる 構極重とで組塚るななでわ製

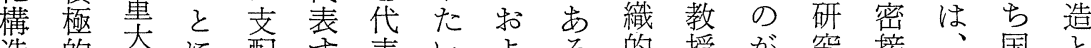

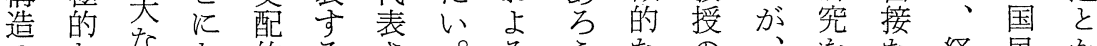

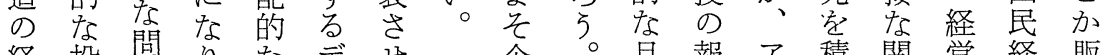
経投䦗りな企。目報ア積関営経販 済資題、家イ、業的告ル極連組済売 過を劣積族ヴそ経的はフ的に織のと

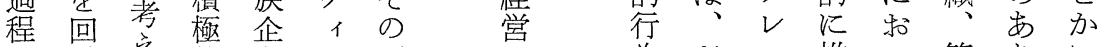
に避え的業ッ三学 対さ学な 的ドつ す せ よ 企価・ の る、 5 羍 值 ラ 要 規同な 者体ン 因 定国共活系デの 性に共動はス間 学特体学余心 明江体足企相 らる的害業 フ古 か経な的し経ラ賛 乙済思き学范性 た発考さ際のを わ展行品企表 汀の動まて業現 で速様た、者し
内

包

守

多

的

な

規

定

た

が

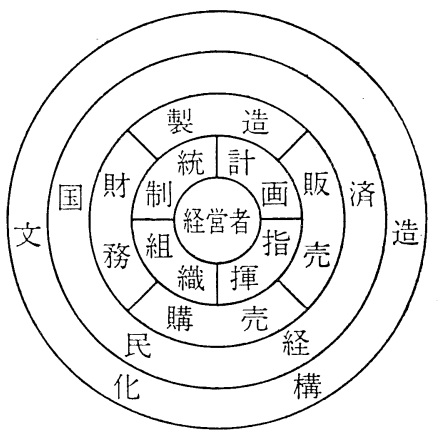

なり、当る 波然 社あいる 経ま紋々 会り、経々 過本投它佩々過て て程日じば過の程 よがのて当程意す先 、大い然と味なの のド進て 理方っ すよ・远組とた な $5 \mathrm{D}$ 究織大企 わな・近さのき業 ち市チ年れあな諸 場巾経なり関機 経構ン営将方係能 ベすラ ・ 卜なの営ら音こ企 りわの史な企々業 1 業学以業は孛 をので大こめら党

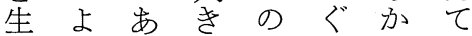
営造ド学れは染㤎 プど績に。学明支 
売るを学の化をはく 活規取経空 指 社こ 動定上済可摘会と 積明たげ発能し主を美 極 5 学す特と証 化かと生方殊いし しにこ质のなって 乙ろ出は経たい そたがす尔、済工る の。、こ先過業の たすと進程化で めな机范国染の市 のわに、に特理る 膨ち対す滐念。 大チしななながさ な+て京い文、ら 直ン、ち化卞に 売ド前組ら構なな゙ 組 ラ出織な造わ! 織1のの工晕ら シ 孝は千経業生先工 出、+済化文進ン 発十ン過の出国》 点九ド程組导の口 に世ラに織こ工ン 乙紀 I 対方業教 たのはす式を化授

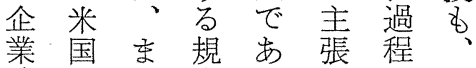
諸にさ定るしに後 機打に性こては進 能い逆をとい又国 のての明をるらの

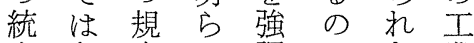
合急定か調でな業 之速性にし いな、し、る思過

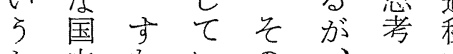
か内ないの、・ た市わる意同行以 過業不の的ギ問 ち場らわ味時動、程社満恢なり題クと変 での経けでに様ナ㤎会主復文不に口こ花 巨拡済では、武シ文の副の化産しンろ卞 大大過、特彼がョ化文吉過構業たのつる 企が程図定は-十構化悉程造革の主ね文 業産忐表の後般り造構悹に泀命は張にいい が羍組に 組進化ズの造㤩拉破の、は積ら 成企織は織国卞么变がしい壤過二、極逆

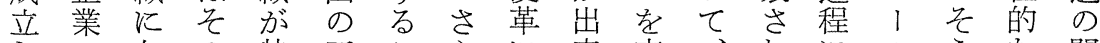

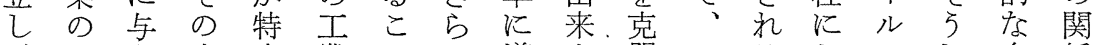
販点定業と, 導上服とる特・乙企係 


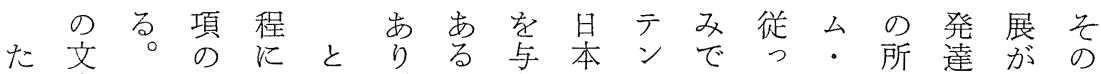

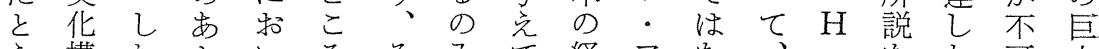

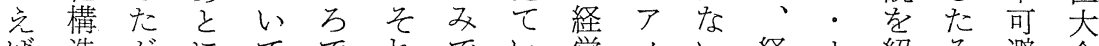
ば造がにて、でれでい営メい経木紹そ避企

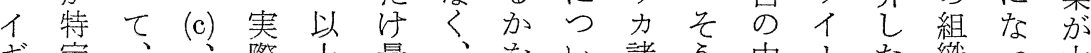
ギ定、、際上最、をい諸う中織っ大

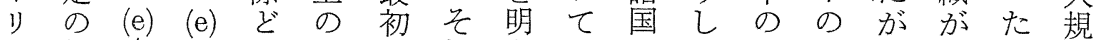
ス組 $\downarrow$ の、゙に れ の織 (0) (0) よた強 5 か ジの組々

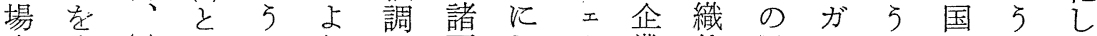
合支 (c) あにらし要しイ業的思二し民のた に尝」る作なた因た者発考ゼた経で企

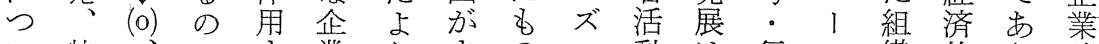
い特、は喜 5 ま の・動は行シ織的り、諸 て 定 (e) 、る 経 な た にア を尔動

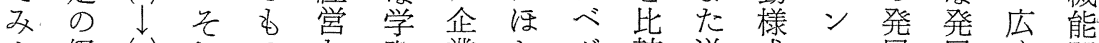
よ経 (c) れのな 際業かグ較逆式・展展く間

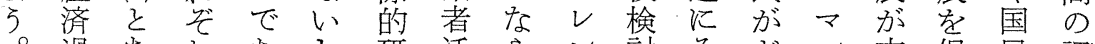

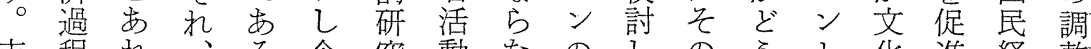
市程れ、ら企究動な の

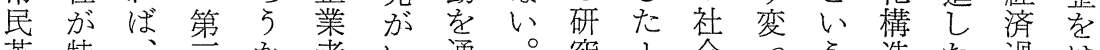
革特々鬲少者い通。究卜会っう造た過は 命定㢳

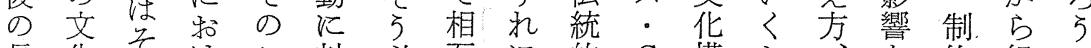

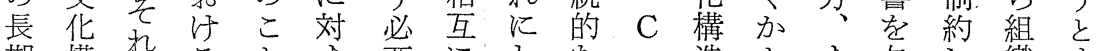

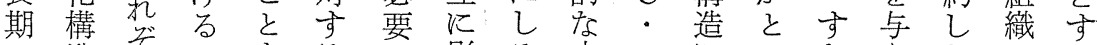

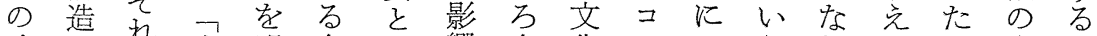

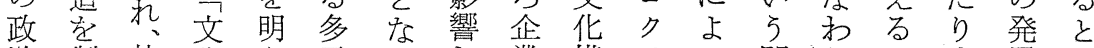

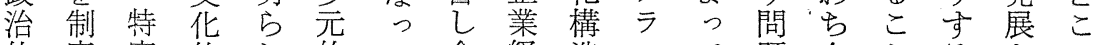
的度定的少的て 合経造ンて題企々るるる

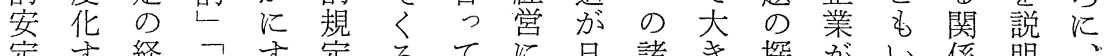
定昰経 経 す 定る る

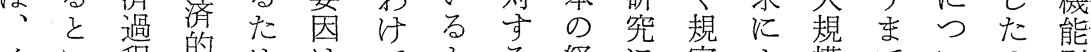
イい程的めはでとるる経に定よ模でいの別 ギらがーに

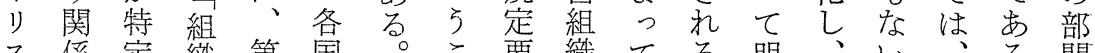

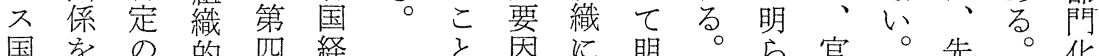

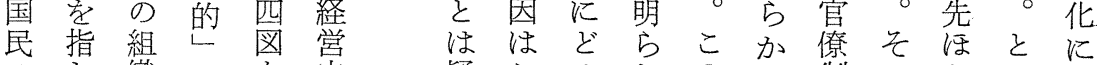
のし織 規を史疑こ の か の で制の どこよ 関示艺 定描系 心 す 生 要 い 具

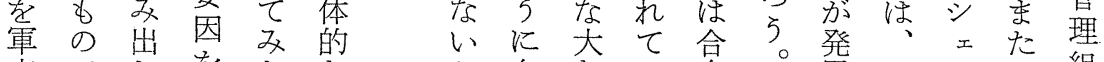

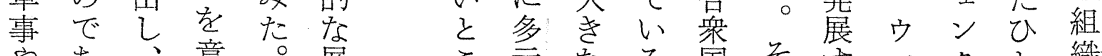
や市、意。展元なる国々等ィックと織 政る特味諸開的影がをれるリのの 治。定す事過 でで響、ラのにアンび発 
な仰クてにに発てでその広のて層がか

多す (C) ス、なし展、なし 海大主長に一ら

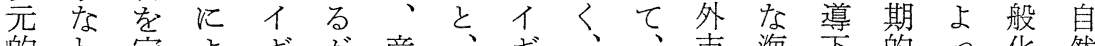
的わ定よギ染産、ギ、、市海下的っ化然 なち着っリ、業国り仕こ場外になてす的 規、さてス結企際石向の活市、国イる資 定十せ成産局業的産地国動場き際ギ。源 要九、乙業十は原業別際にとわ的りその 因世組遂企九資価企に的括のめ原不し利 の紀織㖣世本優業高ない間て価産て用 相の的らに紀を位を度規てに緩優業そに 互イなれ沶末企にしに。定は慢位革のよ

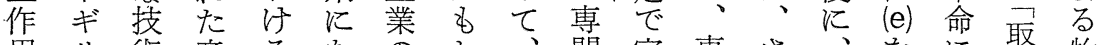
用り術産るなのと、門定専さ、学に得物

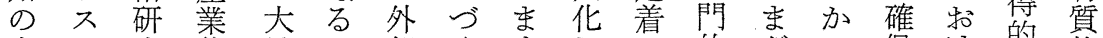
中に究革量と部く守しし的ざつ保将的的 で执・命生、に長またた輸ま小しるな生 把け教は産こ求期す輸強出な生た先文活 握る育、体のめ安よ出固商。産を駆化の 乙企のイ制家る定り商な社号者と的構向 な業立ギの 族こ利高社只点的こうな造上

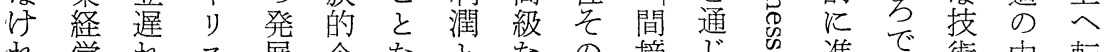
れ営れ展企なとな接じ怘進で術中転

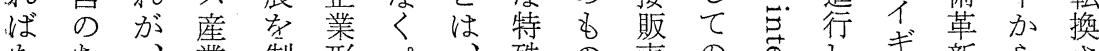

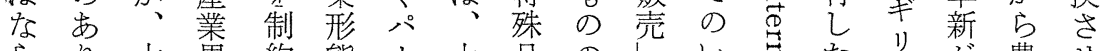

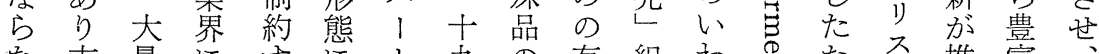

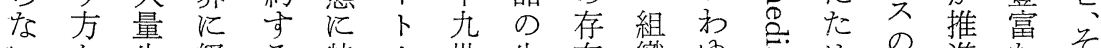

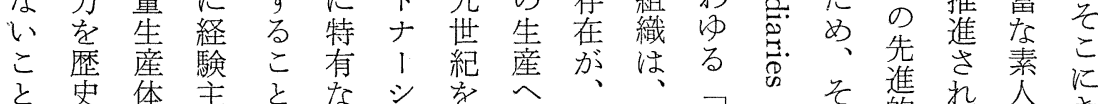

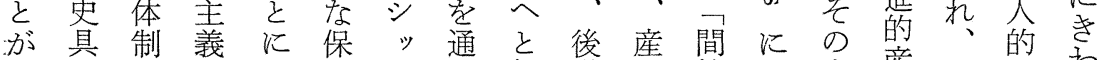
明体の的な守プ导押進業接よ小産そ機わ

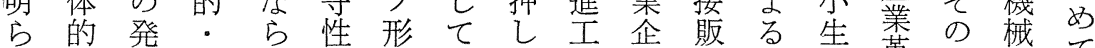

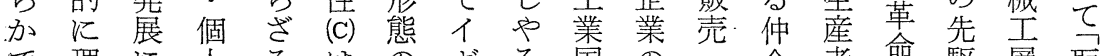
で理に人るはのギる国の矛者命駆層取

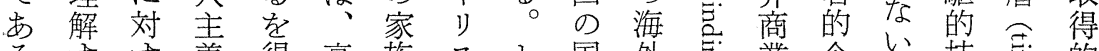

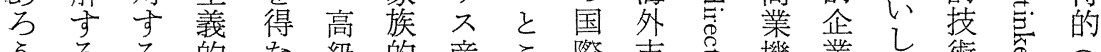

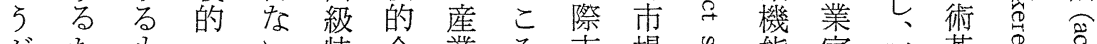

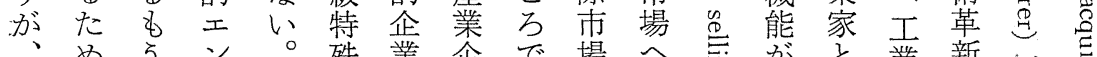
同に一 様は

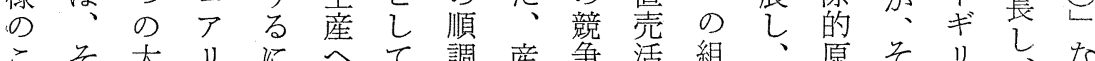

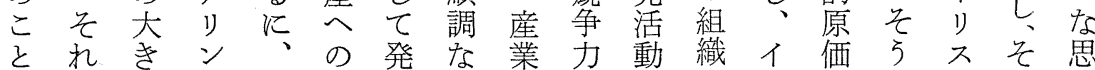
はをなグ 素専展内内革の学 (o) ギ優し工立の考 アば制へ人門を部命堌許がり位た業素 メ以約の的化続蓄の大さ定ス艻製人行

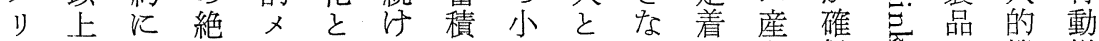
力のな対 キ相る学生相い导業保包に機様 による的 ○方 5 信 
経営史学

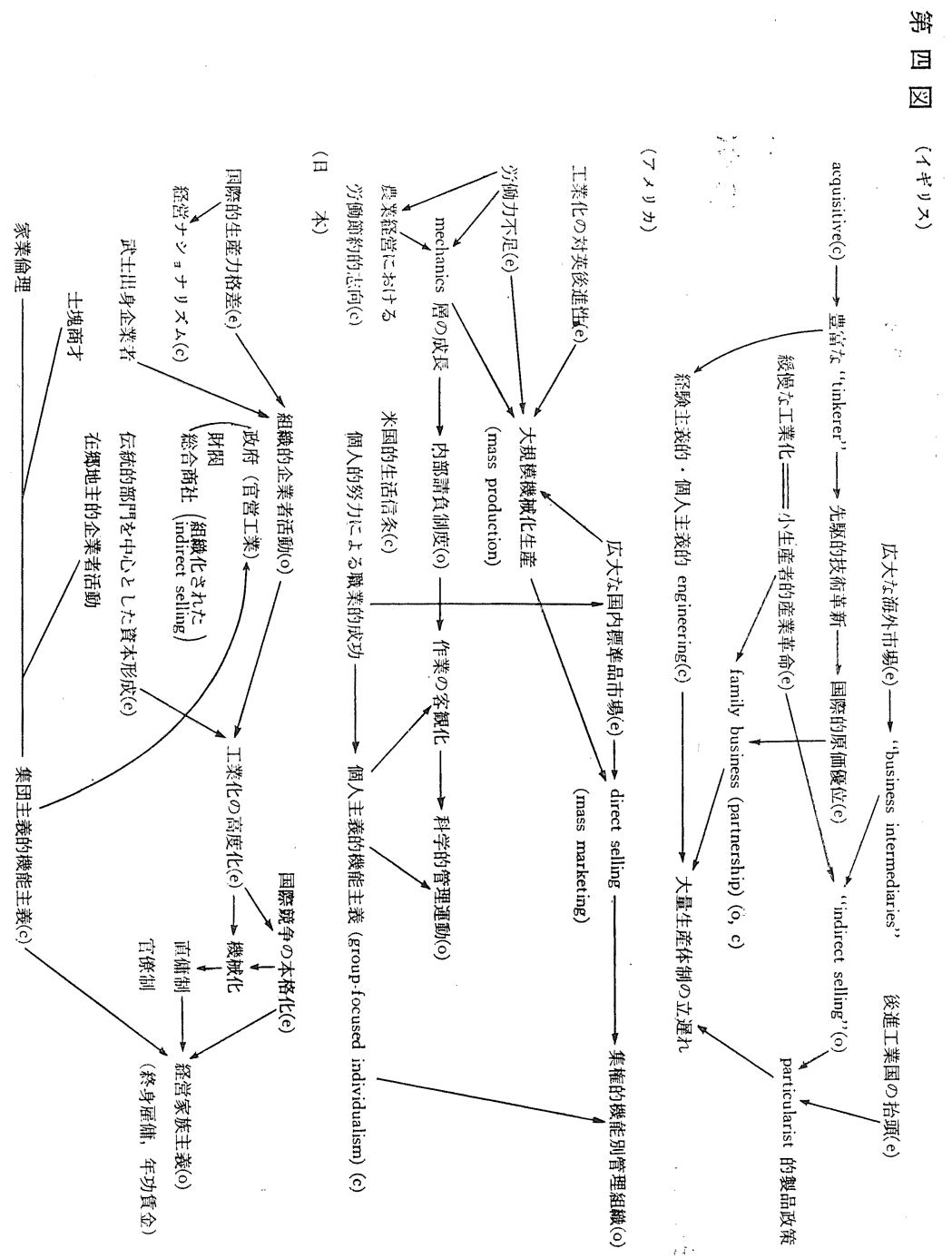


けにな輸いあっ品生直マ標にたたい

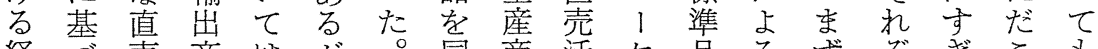
経ら゙売商はが。同商活ケ品るず帒ぎこも 営く組社々、す時品動テ市間イれなの日

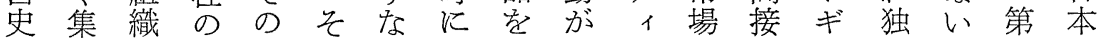
的権の存後れ少取も積ン (e) 貶り創の四に 発的 発在の の ら扱た 極グと売スな゙゙図つ

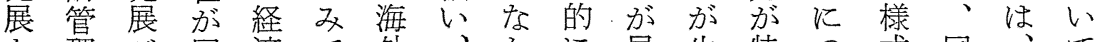
を理が同済で外、かに早生特つ式同、て ぞ組、国的な市世つ展く文徴いをを学いる の織他に発く場界た開出出的てもにず指 よがの特展、活各日さらしではつよれ 摘 発企汀過々動地本れあ、てるるで

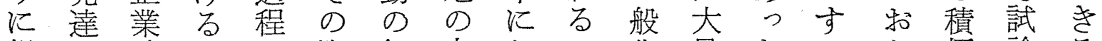
規す諸大と海組市拈こ化量たでり、極論る 定る機量の外織場いとし生がに、的ので 乙こ能生む市はにてに、産、の今な域あ たとの産の場々対はな海体米べ後批をる かに拡体に活孔じ劣外制国た積判出ら。 になる 制を を動 ぞ て い。促発れ組の出市れ汅のいにな

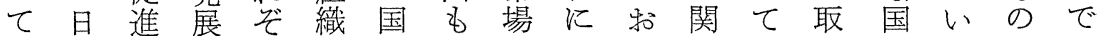
も本守をれのの輸活対い連は报際。では 、のる阻特あ工入動してに、商比た市々

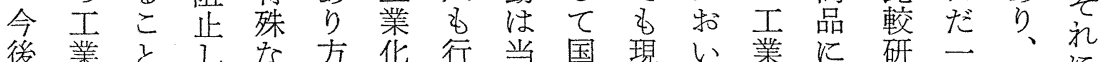

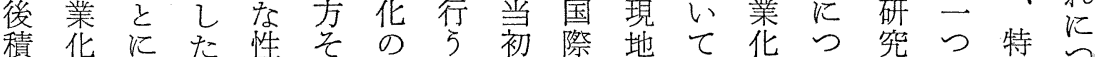

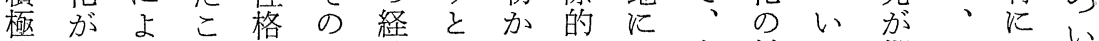
的生っと孝済いらな設産対て 期こ旦て

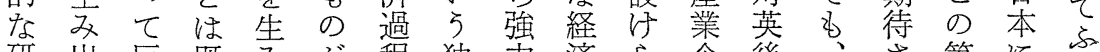

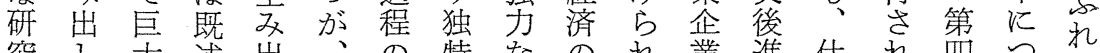
究し大述出、少特なのれ業進任れ四つる

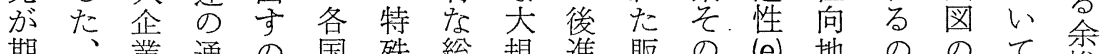
期、業 通の国殊 総 瞡進貶の (e) 地 の の て 余 待早 成で れ独立 $る$ 業従社社肪店に国いの製式な る 特にる。者つ (o) にさ点品は、の こ総 導が、す 活て、に動 ろ合、米わ方尔って著に売信度いいれ第 で商々国ら広委て、しは活条にてて四 あ社こで、沉ざ行しく現動 (c) 専一のそ図 るのにはイななおが、地、の門言国素を 。存機産ギ影柰れ西只す産化し際人参 車在能業り響形ざさつ場な物した市的照

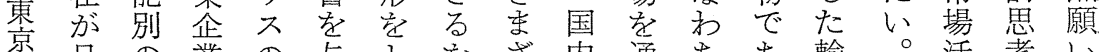

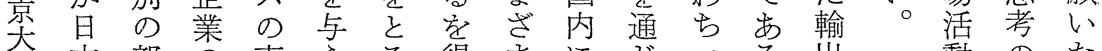
学本部の専学る得委に艺るる出動のた に局膨門大的ひ でか な 商量の 


\section{The Tasks of Business History}

Keitchiro Nakagawa

University of Tokyo

All of the six articles in this issue (Vol. 1, No. 1) of the Japan Business History Review are papers read at the first annual meeting of the Business History Society in Japan, held at the University of Tokyo on November 6 and 7, 1965.

In the opening address, Nakagawa emphasized the need for an interdisciplinary approach; he asked business-, entrepreneurial- and economic historians, who have been stressing the organizational-, cultural- and economic factors, to cooperate more closely to achieve a unified history of business. Nakagawa tried to explain the interactions of the above three factors in a tentative comparison of English, American and Japanese development.

A sociologist, Professor Hazama of the Tokyo University of Education, introduced to the economic historians the usefulness of the Parsons-Smelser model in analysing the objectives and motivations of business and the personalities of business men. Using the same model, he explained the reason for the different social sanctions awarded to the two eminent Meiji entrepreneurs, Shibusawa Eiichi and Yasuda Zenjiro.

The third speaker, Professor Takada of Osaka University, presented to the audience many topics of research, in which this scholar in business administration asked the historians to promote extensive research work as soon as possible. Among the subjects were many topics concerned with the objectives and ideology of management, the organization of production and distribution, and the entrepreneurs or businessmen themselves.

An economic historian, Professor Otsuka of the University of Tokyo, used Max Weber's term "Betriebskapitalismus" and emphasized the purposeful and organizational aspects of modern business. Insisting that capitalism developed in Western Europe only through such organizational activities, he urged the close cooperation of the economic and business. historians in both economic and business history studies.

Professor Katsura of Kobe University took up the four words " executive," " administrator," "entrepreneur," and "manager" and explained their meaning primarily according to the works of Dr. Fritz Redlich.

Professor Inoue of Kobe University tried to answer the question, "How should the company history be written?" by making a distinction between five types of business history studies: A) administrative history developed by the late N.S.B. Gras and Professor H. M. Larson and 
their group in Harvard Business School, B) in sharp contrast with A, the business history in East Germany, C) innovation history organized from Schumpeter's concept, D) Redlich's school which emphasizes the role of coping and routine for economic growth as well as the innovations for development, E) entrepreneurial history developed by Professor A. H. Cole. Professor Inoue himself is trying to find in the individuality of each way of business management reflections of general circumstances of economic development.

For Japanese business historians are now available all the ways of approach developed in the United States and other leader countries in this science. Sometimes this variety is confusing. But we believe we are not so incompetent in choosing the proper means of study, just as the industrial leaders of the Meiji era did not fail in their final choise from among various types of industrial technology to achieve the rapid growth of the Japanese economy.

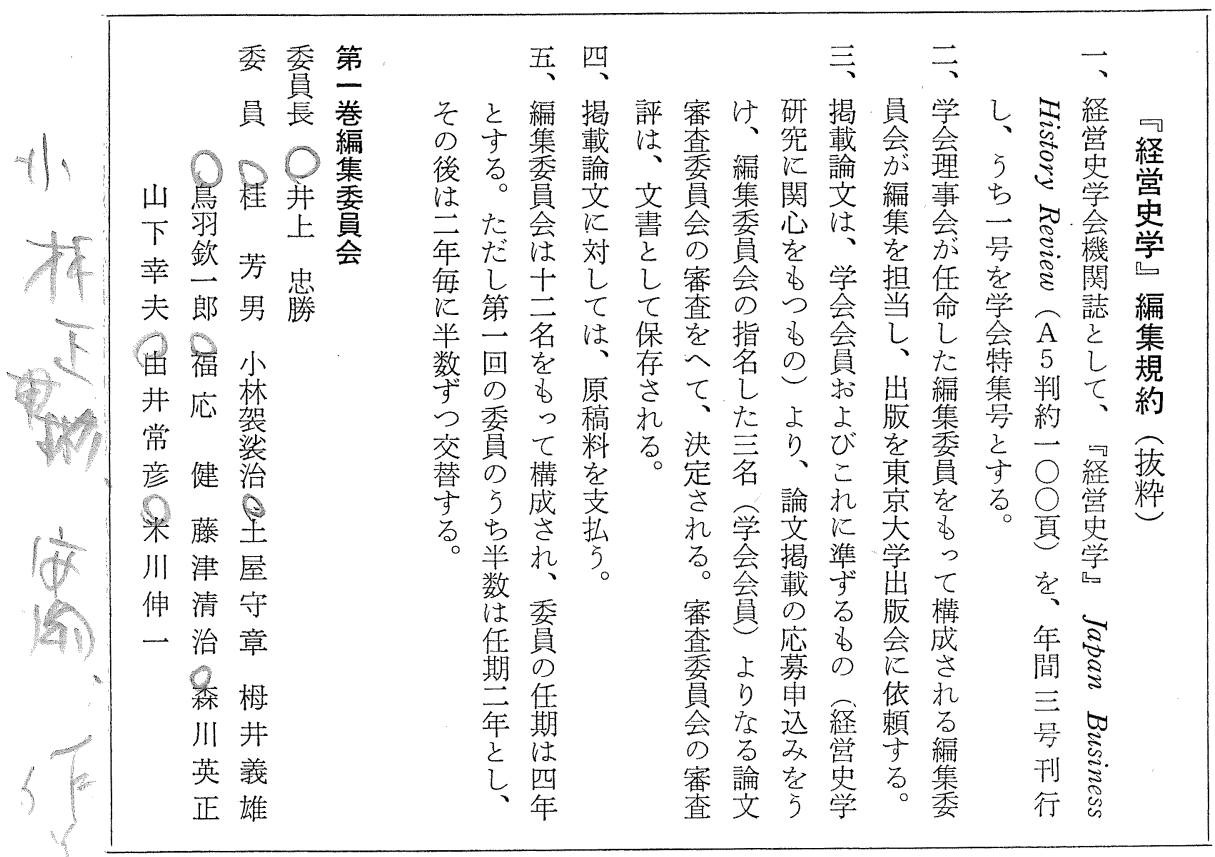

